C. DETECTING SYSTEMS 


\title{
SOLUTIONS OF SOME HIGH POTENTIAL PROBLEMS IN ROCKET EXPERIMENTS
}

\author{
H. HESSBERG and J. NIEKERKE
}

Max-Planck-Institut fïr Physik und Astrophysik, Institut fïr extraterrestrische Physik, Garching, Germany

Corona-problems severely can effect absolute calibrated photomultiplier-experiments in sounding rockets. Solutions in case of experiment R-130 (absolute spectral photometry of B-stars in the vacuum UV-region) are presented.

(To be published in Raumfahrtforschung, Berlin/Stuttgart/München.) 